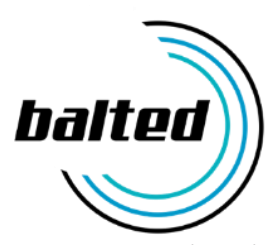

Balkanlarda Türk Dili ve Edebiyatı Araştırmaları

Studies on Turkish Language and Literature in the Balkans Cilt 3/Sayı 1/Kış 2021 - Volume 3/Issue 1/Winter 2021

ss-pp: 1 - 23

Duranlı, M. (2021). Çarlık Rusya'sında Balkan Topraklarının Dil, Kültür ve Coğrafi Açıdan İnceleme Çalışmaları. Balkanlarda Türk Dili ve Edebiyatı Araştırmaları, 3(1), 1-23. DOI: 10.47139/balted.834203

\title{
Çarlık Rusya'sında Balkan Topraklarının Dil, Kültür ve Coğrafi Açıdan İnceleme Çalışmaları
}

Studies of the Balkan Lands in Terms of Language, Culture, History and

Geography in Tsarist Russia

\section{Muvaffak DURANLI*}

\section{Öz}

Rusya'da bilimsel araştırmaların tarihi genel olarak Rusya Bilimler Akademisi'nin kuruluş tarihi ile bağlantılı görülmektedir. I. Petro tarafından temelleri atılan Bilimler Akademisi zaman içinde bünyesindeki enstitü, araştırma birimlerini çoğaltarak günümüze ulaşmıştır. Bilimler Akademisi bünyesinde yer alan araştırma birimlerinden biri de Rus Coğrafya Derneği'ydi. Dernek adını benimseyen bu kurum, temelde Rusya sınırları içinde yer alan bölgelerde çok yönlü araştırmalarla hem ülkenin politik çıkarlarına hizmet etmiş hem de her bölgenin çok yönlü (ekonomi, doğal zenginlikler, madenler, coğrafya, etnik yapı, halk bilimi) incelenmesini sağlamıştır. Kurumun bazı çalışmalarının Rusya sınırları dışında da gerçekleştiği bilinmektedir. Fakat farklı nedenlerden dolayı Balkan toprakları Rus Coğrafya Derneği'nin inceleme kapsamı dışında yer almıştır. Balkan bölgesinin ve bu bölgedeki halkların incelenme tarihi, XIX. yüzyııı ortalarına rastlamaktadır. Bu dönemde Balkan topraklarında görevli bulunan Rus diplomatlar, ilk çalışmaları gerçekleştirmiştir. Genel olarak, bu çalışmaların temel amacı Balkan topraklarındaki Hristiyan ve Slav kökenli halkların Rus okuyucusuna tanıtılmasıdır. Bu nedenle diplomat, seyyah ve gönüllüler eserlerinde, mektuplarında Balkan topraklarındaki Slav halkları ve onların yaşamı, dilleri, gelenekleri ile ilgili gözlemlere yer vermiş, Rus diplomat Konstantin Leontyev ise gözlemlerinden hareketle Balkan halklarının temsilcilerinin kahramanı olduğu edebî eserler kaleme almıştır. Makalede Balkan topraklarındaki Slav halkları üzerinde yoğunlaşan bu çalışmaların yapısı hakkında genel bilgiler verilmeye çalışılacaktır.

Anahtar Kelimeler: Slavistik, Panslavizm, Balkan, Hristiyan, Müslüman, Türk.

\begin{abstract}
The history of scientific research in Russia is considered to be related to the date of foundation of the Russian Academy of Sciences. The Academy of Sciences, founded by I. Petro, has survived to this day, increasing over time its institutes and research units. One of the research divisions of the Academy of Sciences was the Russian Geographical Society. This institution, called the association, served the political interests of the country, conducting diverse research in regions within the borders of Russia, and providing a multifaceted study of the region (economy, natural resources, minerals, geography, ethnic composition, folklore). It is known that some of the activities of this institution are carried out outside Russia. However, for various reasons, the Balkan
\end{abstract}

\footnotetext{
"Doç. Dr., Ege Üniversitesi Türk Dünyası Araştırmaları Enstitüsü, Türk Dünyası Edebiyatları Anabilim Dalı, m_duranli@hotmail.com, ORCID: 0000-0002-4529-2700
} 
lands were not included in the scope of study of the Russian Geographical Society. The history of the Balkan region and the peoples of this region coincides with the middle of the XIX. century. Russian diplomats working in the Balkans during this period carried out the first studies. In general, the main purpose of these works is to acquaint the Russian reader with the peoples of Christian and Slavic origin in the Balkans. For this reason, diplomats, travellers and volunteers included observations of the Slavic peoples in the Balkan lands, their life, languages and traditions in their works and letters, and the Russian diplomat Konstantin Leontiev wrote literary works in which, based on his observations, representatives of the Balkan peoples acted as heroes. In this article, we will try to provide general information about these studies, focusing on the Slavic peoples in the Balkans.

Keywords: Slavistic, Panslavism, Balkan, Christian, Muslim, Turkish.

\section{Giriş}

\section{Rusya'nın Balkan Politikası}

Rusya'nın Balkan politikası temelde bu coğrafyada yaşayan Slav kökenli ve Hristiyan inanç sistemindeki halklarla bağlantılıdır. Özünde Panslavist bir ruh içeren bu politika, Rusya'nın büyüme çıkarlarına hizmet etmektedir. Araştırmacılar bu politikanın özünü oluşturan Panslavist teorinin gelişimini şu şekilde değerlendirmektedirler.

"Tarih boyunca Balkanlar'daki tüm Slav ırklarını bir araya toplamak ve Akdeniz'e inmek Rusya'nın en büyük amacı olmuştur. Önce kültürel bir akım olarak ortaya çıkan Panslavizm, 19. yüzyılda siyasi bir renk almıştır. Bu akımdan önce ise, Balkanlar'da Panortodoksluk hâkimdi. Rusya, özellikle Türk idaresinde yasayan Ortodoksları korumayı, kendisine verilmiş kutsal bir görev olarak algılıyordu" (Aslanova, 2008, s. 1).

Gerçekte Rusya'nın Balkan politikasında etkin olan Panslavizmin temellerinin XVI. yüzyılda ortaya çıktığını belirten Akdes Nimet Kurat, Galip Çağ, Panslavizm kavramının ilk olarak Slovak yazar ve hukukçu Jan Herkel'in (1786-1853) kullandığını belirtirler:

"Panslavizm kavramı ilk kez 1826 yılında Slovak yazar J. Herkel tarafından kullanılmışır. Herkel, umumi Slav dili ile alakalı Latince kaleme aldığı eseri, "Elementa Universalis Linguae Slavicae e Vivis Dialectis Eruta et Suis Logicae Principiis Suffulta" da tüm Slav dillerinde ortak olarak kullanılan yaygın yapı ve kelimeler üzerinden yola çıkarak "verus panslavismus" (hakiki Panslavizm) ifadesini kullanmışıır. Herkel, Slav birliğinin sağlanmasında bilhassa kültürel alışveriş üzerinde durmuş ve bu sayede siyasi birliğinde sağlanabileceğini ifade etmiştir" (Çağ, 2008, s. 212; Kurat, 1953, s. 242). 
Doğu Avrupa Slav toplumunda gelişen bu akım, zaman içinde Rusya'nın Balkan halkları ile ilgili yaklaşımında temel doktrine dönüşmüş ve bu akımın yansıması olan Slav Hayır Dernekleri ilk olarak Petersburg ve Moskova'da açılmıştır.

“Moskova Slav Komitesi ile alakalı ilk çalışmaları N. Popov (1833-1891)1 başlattı. Popov, 1840 'lı yılların sonlarına doğru içlerinde fikir adamları ve siyasetçilerin de bulunduğu bir grup arkadaşı ile beraber Balkan halklarına yardım fikrini ortaya attı. 1853 yılına gelindiğinde Popov daha etkin siyaset izleme gereğini hissetti. İngiltere, Fransa ve Osmanlı Devleti'ne tek başına karsı koymasının zor olacağını anlayan Rusya, ilmî şahıslardan referans alan siyasetçilerin fikirleri doğrultusunda sadece Balkanlar'da değil, aynı zamanda Doğu Avrupa'da da kendisine destek bulmak amacıyla bütün Slavların bir arada olabileceği bir komite kurulması fikrini ortaya attı" (Demiroğlu, 2009, s. 146).

Moskova'da Slav Komitesi'nin kurulma hazırlıkları başlasa da ilk Slav komitesi, “1856 yılında Peterburg'da üç bayandan (Prenses G. V.Vasilçikova, Kontes P. D. Protasova ve Kontes A. D. Bludova) oluşan yardım komitesi kuruldu. Komitenin temel amacı Balkan yarımadasındaki okul ve kiliselere kitap ve dini malzeme temin etmek olarak belirlenmişti" (Nikitin, 1960, s. 27).

Daha sonra Moskova'da 1858 yılında, ardından Kiev'de 1869, Odessa'da ise 1870 yılında ardı ardına Slav Komiteleri açıldı. Araştırmacı Aleksey Aleksandroviç Popovkin, bu komitelerin, özellikle de Moskova'daki Komitenin Balkan topraklarındaki Slav halkları tarafından memnuniyetle karşılandığını ve sık sık Moskova'ya teşekkür mektupları geldiğini ve hatta Moskova Slav Komitesi üyesi tüccar i. İ. Çetverikov'a 1869 yılında II. Derece Prens Daniil Karadağ nişanı verildiği belirtilmektedir (Popovkin, 2011, s. 271).

Panslavist doktrinin ideologlarından biri olan Niolay Yakovleviç Danilevskiy (1822-1885), 1871 yılında Peterburg'da yayınlanan "Rusya ve Avrupa" (Rossiya i Evropa) adlı kitabında bu doktrinle ilgili düşüncelerini belirtmiş ve İstanbul'un da Slav birliğinin başkenti olması gerektiğini ileri sürmüştür:

“Tek kelime, Tsargard² Rusya'nın değil, Bütün Slav birliğinin başkenti olmalıdır" (Danilevskiy, 1991, s. 384).

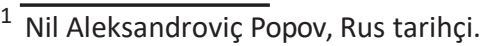

${ }^{2}$ Genel olarak bu dönem kayıtlarında İstanbul adı yerine ya Konstantinopol ya da çoğunlukla Tsargrad adı kullanılmaktadır. Tsargrad adı, "tsar" (çar) ve "grad" (şehir) kelimelerinin birleşiminden gelmekte ve İstanbul, "Çarların Şehri" veya "Çarlar Şehri" olarak tanımlanmaktadır.
} 


\section{Balkan Çalışmalarının Başlangıcında Slavistik}

Genel olarak Balkanlardaki Slav halkları ile ilgili çalışmalar Çarlık Rusya'sında Slavistik çalışmaları bünyesinde yer almıştır.

XIX. yüzyılın 30'lu yıllarından itibaren Peterburg Üniversitesi mezunu, eski Slavca üzerine çalışmaları ile tanınan Aleksandr Hristoforoviç Vostokov'un (17811864) öğrencisi Petr İvanoviç Preys (1810-1846), Batı ve Güney Slav dilleri ile ilgilenmeye başladığı bilinmektedir. Onun Slav ülkelerinde ve daha sonra Almanya ve Avusturya' daki Slav toplulukları arasında beş yıl boyunca sürdürdüğg̈ çalışmalardan sonra Peterburg Üniversitesi'nde açılan Slav Araştırmaları bölümünün başkanlığına 1843 yılında getirildi (Bulahov, 1978, s. 64).

Preys'in 1846 yılında ölümünden sonra bölüm başkanlığı Harkov Üniversitesi'nden gelen İzmail İvanoviç Sreznevskiy'e geçti.

i. S. Sreznevskiy (1812- 1880), özellikle Slav dillerinin geçmişi üzerinde yoğunlaşmaya çalıştı, onun "Rus Dili ve Diğer Slav Lehçeleri Tarihi ile ilgili Düşünceler" (Mısli Ob İstorii Russkogo Yazıka i Drugih Slavyansih Nareçiy) adlı çalışması (Peterburg, 1858, 1857) Slavistik çalışmalarına yön vermiş, ilk çalışmalardan birisidir (Bulahov, 1978, s. 68).

Balkan çalışmalarının bu ilk döneminde genel olarak üniversitelerde eski Slavca ve Balkan Slav halklarının dilleri ile ilgili karşılaştırmalı çalışmalar yapıldığı görülmektedir. Bazı araştırmacılar ise çalışmalarını "Eski Slavca" ya da "Kilise Slavcası" olarak tanımlanan dil üzerine yoğunlaştırmışlardır. Üniversite bünyesinde gerçekleştirilen dille ilgili bu çalışmalarda Balkan halklarının tarihi, kültürü, gelenekleri ve yaşam biçimi göz ardı edilmiştir.

Aleksandr Nikolayeviç Pıpin de XIX. yüzyılın ilk yıllarında Balkanlardaki Slav halklarına seyahatlerin yapıldığını, fakat bu seyahatnamelerin şimdi unutulmuş olduğunu ve günümüzdeki bilimsel araştırmalarda bu ilk yazılara ilgi ile bakılmadığını belirtir. Ona göre bu seyahatnamelerin ilki D. N. Bantış- Kamenskiy'e aittir (Pıpin, 1889, s. 241).

Dmitriy Nikolayeviç Bantış- Kamenskiy (1788- 1850), 1808 yılında Sırp Mitropoliti Leontiy'in ricası üzerine Rusya'dan Sırbistan'a kutsal nesneler götürme görevi ile Balkanlara seyahat etmiştir. Bantış- Kamenskiy'in Belgrad'ın ve bazı kutsal mekânların ayrıntılı tasvirini içeren bu seyahatnamesi, 1810 yılında Moskova'da yayınlanır. "Moldova, Eflak ve Sırbistan'a Seyahat" adını taşıyan bu kitap, arkadaşlara mektuplar sitilinde kaleme alınmıştır (Polienko, Srinyak, 2018, s. 224).

Kitaptaki en ilginç anlatım, bu tarihte bir isyan başlatmış olan Sırp Kara Yor- 
gi'nin tasviridir. Orijinaline ulaşamadığımız bu tasviri A. N. Pıpin çalışmasında vermiş ve bu cümlelerin Bantış- Kamenskiy'in kitabının 127- 128. sayfalarında olduğunu belirtmiştir.

"Bana söylediklerine göre, Kara Yorgi kırk yaşlarındaydı. Uzun boylu, geniş omuzluydu, yüzü uzunca idi... Saçları arkadan saç örgüsü olarak örülmüş, bütün sırtını örtmüştü... O zamanki köylüler gibi çok basit giyiniyor, her zaman iki tabanca ve büyük bir bıçak taşıyordu. Çok güzel değildi; samimiydi, sohbette suskundu, ondan bir kelime duyamazdınız, ancak votka içerken bir dua okurdu; ne okuması ne de yazması vardı, başarılarla süslenmiş cesareti onun bütün dünyada tanınmasını ve Sırpların kumandanı olmasını sağlamıştı (Pıpin, 1889, s. 243).

Pıpin, Balkanlardaki Slav topraklarına giden diğer bir seyyahın da Vladimir Bogdanoviç Bronevskiy (1784- 1835) olduğunu belirtir ${ }^{3}$. Ona göre, gerek Bantı̧̧Kamanskiy gerekse de Bronevskiy duygusal nitelikte, Slav kültürüne katkı da bulunmayan iki seyyahtır ve bu nedenle çalışmaları unutulmaya mahkûmdur (Pıpin, 1889, s. 245-246).

Biz, daha 1889 yılında yazdığı makalede bu iki seyahatnamenin de zaman aşımına uğradığını belirten akademisyen Aleksandr Nikolayeviç Pıpin'in (18331904) görüşlerinden hareketle bu seyahatler üzerinde durmayacağız. 1800'lü yılların ortalarında görevleri gereği Balkan topraklarında bulunan Rus diplomatların gerek dil, kültür gerekse yaşam biçimi, inanç ve gelenekler üzerinde yoğunlaşmış çalışmalarına değinmeye çalışacağız.

\section{Balkan Çalışmalarına Temel Oluşturan Rus Elçilik Görevlileri}

Rusya'da Balkan araştırmaları kurumsal düzeyde gerçekleştirilmesinden önce, bu topraklara ilgi duyan bazı Rus elçilik çalışanlarının Balkan kültürü üzerine çalıştıkları bilinmektedir. Özellikle Çarlık Rusya'sında Balkan topraklarındaki Slav halkları arasında yaptığı derleme çalışmaları ile ünlenen İvan Stepanoviç Yastrebov adı bu alanda ön planda yer almaktadır.

\section{İvan Stepanoviç Yastrebov}

27 Ocak 1839 tarihinde Tambov vilayetinde doğan Yastrebov, 1894 Ocak ayında Selanik'te vefat etmiştir. Daha çok kaynaklarda diplomat olarak anılan İvan Stepanoviç Yastrebov, İstanbul'daki Rus konsolosluğunun sekreteri olarak çalıştıktan sonra Prizren'de konsolos, Selanik'te başkonsolos görevlerini de dürdürmüştür.

\footnotetext{
${ }^{3}$ Aleksandr Nikolayeviç Pıpin'in üzerinde durduğu bu çalışma Peterburg'da 1836 yılında yayınlanmıştır. Kitabın adı “Akdeniz'de Amiral Dmitriy Nikolayeviç Senyavin'in Komutası Altında Çalışan Bir Deniz Subayının Notları" başığını taşımaktadır.
} 
Yastrebov'un hayatını ayrıntılı bir şekilde ele alan Terziç, Mayıs 1866 tarihinde "Sırp başkenti Prizren'de" benzer bir kurumun açılmasından sonra Yastrebov'un 1 Nisan 1870 yılında Prizren'e geldiğini belirtmektedir (Terziç, 2014, s. 127).

Onun temel çalışma konusu Osmanlı yönetimi altındaki Sırpların kültürü olmuştur. Onun yıllar içinde gerçekleştirdiği derlemeleri, “Prizren, İpek, Morava ve Dibre'de Türk Sırplarının Gelenekleri ve Şarkıları" başlığı ile ilk baskısı (498 sayfa) 1886 yılında Peterburg'da yayınlanmıştır. Daha sonra eserin genişletilmiş ikinci baskısı yine Peterburg'da 1889 yılında (626 sayfa) yayınlanır.

Oldukça hacimli olan bu çalışmada şarkı metinleri dışında farklı bölgelerden derlenmiş bilmeceler (Yastrebov, 1889, s. 582-594), doğum ve ölümle ilgili gelenekler (Yastrebov, 1889: 471- 486) ve Prens Marko (Yastrebov, 1889, s. 299-311) ile ilgili destan metinleri yer almaktadır. Gerek şarkı gerekse diğer metinlerde Türkçe kelimeleri tespit etmek mümkündür. Özellikle çalışmanın son kısmında, 595-626 sayfaları arasında yer alan "Sözlük" bölümünde Türkçe kelimelerin Rusça karşılığı verilmiştir.

Yastrebov, bazı kelimelerin karşısına parantez içinde Türkçe olduklarını belirtmiştir. Politik bir yaklaşımla bazı Türkçeden Sırpçaya geçmiş kelimelere açıklama vermemiş, bazı kelimelerin de Farsça olduğunu göstermiştir. Örneğin "sedef" kelimesinin kökeninin Arapça olduğu, "sevdeli" kelimesinin ise "Türkiye Ermenicesinden" geldiği gösterilmiştir (Yastrebov, 188, s. 618), "şeher" olarak verilen kelimenin karşılığında ne Farsça ne de Türkçe olduğu belirtilmemiş, sadece anlamının "şehir" olduğu Rusça olarak verilmiştir, fakat yine aynı sayfada yer alan ve "şegrt" şeklinde yazılan kelimenin Farsça olduğu ve öğrenci anlamına geldiği belirtilmiştir (Yastrebov, 1889, s. 626).

Yastrebov, bir dilbilimci değildir. Burada bazı kelimelerin Arapça veya Farsça olduğunu belirtmesi, bazı Türkçe kelimelere de hiçbir aitlik açıklaması vermemiş olmasının temel nedeni, bu çalışmada yer alan Türkçe kelime oranını azaltmak olmalıdır.

Yazarın yıllarca süren derlemelerinin yayınlanmasının ardından Sırp kilise tarihini inceleyen "Podatsi za istoriju Srpske tsrkve" adlı çalışması 1879 yılında Belgrad'da Sırpça olarak yayınlanmıştır. Bu çalışmanın ardından 1904 yılında ise yazarın "Eski Sırbistan ve Arnavutluk. Yol Notları" adlı çalışması Belgrad'da yayınlanan Sırp Kraliyet Akademisi yayın organı "Spomenik" dergisinin 41. cildinde Momçilo İvanin'in Yastrebov ve çalışmalarını tanıttığı Sırpça tanıtım yazısının (Momçilo, 1904, s. I- XI) ardından Rusça olarak yayınlanır (Teziç, 2014, s. 125). 
Bu çalışma Sırbistan ve Arnavutluk'u bölge bölge tanıtan bir çalışmadır. Yazar, Sırbistan bölümüne Dyakov bölgesi ile başlar. "Dyakov bölgesi bütün eski fermanlarda Altuneli olarak adlandırılmıştır. Türkler bu adı Dyakov bölgesinin fethettikleri sakinlerinden almışlardır, bu insanlar bölgede Altin adı verilen bir çiftliğe sahiptiler" (Yastrebov, 1904, s. 1).

Yastrebov'un eserinin devamında şehrin ayrıntılı tasviri yer almaktadır. "Şehir on iki mahalleye ayrılmaktadır. Hemen hemen bütün mahallelerin Türkçe adı vardır: Mula Tusufov, Hadumov, Gul mahala, Kerimov, Haci Ömerov... Minareli 16 cami vardır; onlar içinde şehrin ortasında yer alan Adumov camisi külliyedir, minaresiz üç cami ve on iki tekke vardır. Bu camiler içinde en eskisi, Dyakov'da ilk inşa edilen cami, yaptıranın adını taşıyan Dilsiz Süleyman Efendi camisidir. 1596 yılında yaptırılmıştır..." (Yatsrebov, 1904, s. 2).

Yastrebov, yeri geldikçe nüktedan bir üsluba da başvurmaktadır: "Gerek şehrin gerekse köylerin iklimi sağlıklıdır. Eğer insanlar kurşundan ölmezlerse yaşlanıncaya dek yaşarlar" (Yastrebov, 1904, s. 4).

Panslavizme gönül vermiş olsa da Yastrebov eserinde tarihi gerçekleri dile getirmekten kaçınmaz. Daha sonraki sayfalarda ise bölgedeki bir manastırın camiye çevrilmediğini, manastır olarak kullanıldığını, fakat bazı yerel yöneticilerin çeşitli bahaneler ile rahipleri buradan çıkarmak istemesi ve kiliseyi yıkıp altında altın aramak istemesi üzerine Sultan Süleyman'ın 1557 tarihli bir ferman ile rahiplere dokunulmamasını emrettiğini bildirmektedir (Yastrebov, 1904, s. 7).

Yastrebov'un hem Sırbistan hem de Arnavutluk'taki belli başlı yerleşim noktalarını tanıtırken sık sık Osmanlı fermanlarına başvurması, onun bu alana hâkimiyetini ortaya koymaktadır.

\section{İnsancıl Bir Panslavist: Nikolay Konstentinoviç Leontyev}

Rus elçiliğinde görevli araştırmacılardan biri de Konstantin Nikolayeviç Leontyev'dir. 1831- 1891 yılları arasında yaşayan Leontyev, "1863 yılında Dış İşleri Bakanlığı'nda çalışmaya başlar. Ekim 1863'de Girit adasındaki Rus konsolosluğundaki sekreterlik görevine atanır. Girit'teki bir yıllık yaşamı, yazarın edebi çalışmalarında yeni bir sayfa açar, bundan sonraki çalışmalarında Balkan halkları onun temel ilgi alanını oluşturmuştur. "Girit'ten Yazılar", "Hrizo”, "Hamid ve Manoli" adlı eserler bu dönemin verimli ürünleri arasında yer almaktadır. 1864 yılında Leontyev iki yıldan daha fazla bir süre kalacağı Edirne'deki konsolosluk görevine geçti. Edirne, Konstantin Leontyev'e İstanbul'da bulunma ve buradaki kültürü daha iyi anlama imkânı da sağladı. K. N. Leontyev 1867 yılında Tulça'daki konsolos yardımcısı görevine atandı" (Duranlı, 2012, s. 479). 
Konstantin Leontyev'in Türkiye'de yaşadıklarından hareketle yazdığı hikâyeler ilk olarak 1868 yılında "Türkiye'deki Hristiyanların Yaşamından" başlığı ile "Russkiy Vestnik" dergisinde yayınlanmış, daha sonra üç ciltlik kitap olarak 1876 yılında çıkmıştır (Leontyev, 1912, s. 1). Leontyev bu hikâyelerde bazen mektup bazen de düz yazı tekniğini kullanmıştır. Bu anlatılar, Leontyev'in bölge insanlarını ve onların gündelik yaşamını ne kadar iyi tanıdığını ortaya koyar. Hiçbir hikâyede Slav olsun Türk olsun, hiçbir halka karşı nefret yer almaz.

Nikolay Aleksandroviç Berdyayev (1874-1948), Leontyev'in yaratıcılığı ve görüşlerini incelediği çalışmasında Leontyev'in diplomat görevinin onun gelişiminde büyük katkısı olduğunu şu sözlerle belirtir:

“Leontyev'in Doğudaki yaşamı onun yaratıcılığı için büyük kazanımlar vermiştir. Denilebilir ki, onun en önemli eserleri Doğu'da gelişen düşünceler ve yaşanılanların etkisi altında gelişmiştir. Doğu onun ruhsal yönünü kesin olarak şekillendirmiş, politik, felsefi ve dini düşüncelerini aşırı derecede keskinleştirmiş, temelde Türkiye'deki Hristiyanların yaşamına adanmış sanatsal yaratıcılığını ayağa kaldırmıştır" (Berdyayev, 1926, s. 54-55).

Berdyayev'e göre Doğuya duyduğu sevgi onu klasik bakış açılarından da farklı kılmıştır:

“... Doğu politikasında o, onu geleneksel Panslavist bakış açısından kesin olarak ayıran, orijinal bir konum almıştır. K. Leontyev Balkanlardaki Yunanlıları ve Türkleri sevmiş, Slavları, özellikle de Bulgarları sevmemiştir" (Berdyayev, 1926 s. 61).

Leontyev'in İstanbul'da olmaktan duyduğu rahatlık ve onun Edirne sevgisi yakın arkadaşı, tarihçi ve diplomat Konstantin Arkadyeviç Gubastov (1845-1913) ile yazışmalarında ifade edilmiştir.

Leontyev, 13 Ağustos 1875 tarihinde Kudinova'dan arkadaşına yazdığı mektupta İstanbul için şu ifadeleri kullanır. "Ben şehrin kendisini, adaları, Yunanlıları... Emin olun buradaki her şeyi seviyorum. Ne Moskova ne Peterburg ne Kudinova ne de başka bir yerdeki uygun görev, hatta en iyi manastır bile beni Konstantinopol'deki kadar memnun edemez! Boğazdaki fakirlik buradaki zenginlikten daha iyidir... "4 (http://az.lib.ru///leontxew_k_n/text_0700.shtml)

29 Şubat 1868 tarihinde Tulca'dan yazdığı mektupta

“Edirne'nin şiirini tam olarak anlamak için şu öğütlerimi dinleyin: 1. gecik-

\footnotetext{
${ }^{4}$ Leontyev'in bu mektubu ilk olarak "Russkoe Obozrenie" dergisinin 1894 yılı Eylül sayısında yayınlanmıştır.
} 
meden kendinize bir sevgili edinin, basit bir Bulgar kız veya Yunanlı; 2. Sık sık Türk hamamlarına gidin; 3. Zor olsa da bir Türk kadını elde etmeye çalışın; 4. Franklara dikkat etmeyin... ; 5. Sık sık Tunca kıyısında gezin ve beni hatırlayın; 6. Sultan Beyazıt camisine gidin ve orada köşkün yanındaki çayırlıkta davul sesleri eşliğinde genç Türklerin (pehlivanların) güreşini izleyin, bu harikadır!" (Konoplyantsev, 1911, s. 196-197).

Konstantin Leontyev, Türk kültürüne ve Türk aile yapısına karşı saygı duymaktadır. Ona göre, “Aile kavramının bizde zayıf olduğunu iddia ederken Tanrım ben haksız olayım! Eğer benim yanıldığımı, benim bu konuda kötümser olduğumu kanıtlayacak kesin bir istatistik varsa ben mutlu olacağım. Fakat şimdiye kadar bana bunu kanıtlayamadılar, ... Yunanlılarda, Yugoslavlarda, hatta Türklerde aile kavramının bizden daha sağlam ve daha derin olduğu konusunda ısrarcı olacağım” (Leontyev, 1875, s. 24).

Leontyev, Lev Nikolayeviç Tolstoy'un "Hacı Murat” adlı romanından sonra Türkçe bir adı Rus edebiyatına taşıyan ikinci Rus yazarıdır. Yazarın 1869 yılında "Russkiy Vestnik" dergisinde yayınlanan "Pembe"5 adlı hikâyesinde Pembe adlı Çingene kızının Arnavut soylusu Hayrettin Bey’e aşkı anlatılmaktadır. Bu hikâyede o dönem Balkan topraklarında yaşayan her halkın temsilcisini görmek mümkündür: Hayrettin'in arkadaşı Yunanlı Doktor Petropulaki, Hayrettin'in babasının ikinci karısı Yunanlı Marigo, bölge meclisindeki Çerkez kökenli Fehim Paşa, Hayrettin'in uşağı Arap Yusuf, Yahudi banker İşua.

Leontyev'in yarattığı başkahraman Hayrettin, temsil ettiği Arnavut toplumundan farklı özellikler göstermektedir. Yazar, Hayrettin'in hayatının bir döneminde İstanbul'da eğitim almış olması, onu bulunduğu toplumdan daha farklı, daha gelişkin bir birey olmasını sağladığını ileri sürmektedir.

"Hayrettin, orada Avrupa kibarlığını öğrendi; Türkçe, Farsça ve biraz Fransızca öğrendi..." (Leontyev, 2001, s. 112).

Hikâye Hayrettin'in bir Yunanlı tarafından öldürülmesiyle sona erer. Leontyev, hikâyenin sonunda metinde geçen "çiftlik", "devlet", "defterdar", "ferace", "hanum", "selamlık" "yaşmak", "zaptiye" gibi sözcüklerin anlamını vermiştir (Leontyev, 2001, s. 146).

Edebî yaratıcılığında Balkan topraklarındaki halkların anlatılarından, karakterlerinden beslenen Konstantin Leontyev, Rus edebiyatına Balkan imgesini yerleştirmiş ilk Rus yazarıdır.

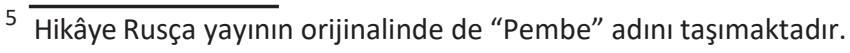




\section{Nefret Dolu Bir Panslavist: Aleksandr Fedoroviç Gilferding}

Leontyev'in insancıllığından ve Yastrebov'un derleme çalışmalarındaki titizliğinden uzak olan AleksandrFedoroviç Gilferding (1831- 1872), Panslavist doktrini desteklemiş olmasına rağmen gerçekte Alman kökenli zaman içinde Ruslaşmış bir aileden gelmektedir. Aile, 1700 'lü yıllarda Rusya'ya yerleşmiştir. Lebedev'e göre, "Gilferding' in ataları Almanya'dan, Saksonya'dan, Büyük Petro döneminde Rusya'ya gelmişlerdir. Aleksandr Gilferding' in dedeleri Yukarı Saksonyalıdır. O zamanlar Polabya Slavlarının yerleştiği bu bölge, XII. yüzyılda Almanlar tarafından silah gücüyle alınmıştı. Doğu Almanya'nın bütününde olduğu gibi, Saksonya'daki Slavların çoğunluğu da birkaç yüz yıl içinde Almanlaşmışlardı" (Lebedev, 2009, s. 5).

Bu açıklamayı vermemizin nedeni, Panslavist doktrinin savunucusu birinin Rus, daha doğrusu Slav halkından olması gerektiğini Gilferding'in çalışmalarını yayınlayanların kabul etmiş olmasıdır. Zira Gilferding soyadı, Rus soy ad sistemine uygun değildir.

Gilferding, 1856-1859 tarihleri arasında Bosna'da konsolos olarak görev yapmış ve bu topraklardaki gözlemlerinden hareketle iki çalışma kaleme almıştır. Onun bu çalışmaları Gilferding hayatta iken birkaç kez yayınlanır: "1858 Yılı Başlarında Bosna" ${ }^{6}$ ve daha kapsamlı olan "Bosna, Hersek ve Eski Sırbistan'da Seyahat"7. Araştırmacı Melçakova bu iki çalışmanın 1859 yııında Sırpçaya da çevrildiğini belirtmektedir (Melçakova, 2017, s. 175).

Aynı yıl içinde iki yazı da 1859 yılında Peterburg'da yayınlanan "Bosna, Hersek ve Eski Sırbistan" adlı çalışmada yer almıştır. Gilferding, adı geçen çalışmasında Balkan yarımadasındaki Slav topluluklarının güncel durumu hakkında bilgi vermiş, köy, kasaba ve şehirleri tasvir etmiştir.

\section{Gilferding'in Sırpçadan Rusçaya Yaptığı Çeviriler Sayesinde Yok Olmaktan Kurtulan Kronik/Kronikler}

Bu çalışmada yer alan en ilgi çekici bölümlerden biri "1825- 1856 Bosna Kroniği" adlı bölümdür (Gilferding, 1859, s. 549- 656). Bu bölümde Gilferding, Sırp rahibe ve yazar Staka Skenderova'nın Sırpça olarak kaleme aldığı yazıyı Rusçaya çevirip yayınlamıştır.

Bu yazı ilk olarak 1859 yılında "Bosna, Hersek ve Eski Sırbistan" adlı kitabının

\footnotetext{
6 Bu eser ilk olarak "Vestnik İmperatorsogo Russkogo Geografiçeskogo Obşçestva” dergisi, 1858, c. XXIII, 69-126'da yayınlanır.

${ }^{7}$ Bu eser de ilk olarak "Zapiski Russkogo Geografiçeskogo Obşçestva, 1859/11860, 13'de yayınlanır.
} 
549- 656 sayfaları arasında, daha sonra 1873 tarihinde yayınlanan "Gilferding' in Eserleri. Bosna, Hersek ve Eski Sırbistan" adlı çalışmanın 379- 465 sayfaları arasında yer alır. Her iki yazıda da "Çevirenin Önsözü" ve Staka Skenderova'nın "Bosna Kroniği" bölümleri yer almaktadır.

Ocak 1858 yıında yazıldığı belirtilen bu kronikte geçen olayların yaşandığı bu dönemde Bosna'da Ali Paşa Rıdvanbegoviç (1783- 1851) etkin bir yöneticidir. Başlangıçta Osmanlıya sadakat göstermiş olsa da daha sonra isyan etmiş, 20 Mart 1851 'de koruması olan askerlerden birinin silahının ateş alması sonucu ölmüştür (Bilge, 2008, s. 51).

Staka'nın kroniğine konu olan bu dönemin Baklanlardaki halklar için oldukça gergin bir dönem olduğu, Gayrimüslimlerin Osmanlı Ordusu'nda istihdamına ilişkin olarak Tanzimat Meclisi tarafından bir karar verildiği araştırmacılar tarafından belirtilmektedir. "... Verilen kararın ilanının ardından Yanya ve Tırhala bölgelerinde bulunan Hristiyan halkın bir kısmı Yunanistan'a, Bosna'da bulunan Hristiyan halkın bir kısmı ise Avusturya'ya kaçmaya başlamış ve Niş Eyaleti'nin Sırbistan sınırına yakın bölgelerindeki Hristiyanların çoğu dağlara kaçmışır. Devlet bunu güçlükle engelleyebilmiştir. Hükümet, Rumeli'de yaşayan on binlerce insanın topraklarını terk etmesi durumunda ortaya çıkabilecek ekonomik, sosyal ve siyasi sıkıntıları göz önünde bulundurarak sınır bölgelerinde yaşayan Hristiyan halktan asker alımını durdurdu" (Çetin, Kök, 2018, s. 18).

Staka Skenderova'nın kroniğinde asker alınması, keyfi uygulamalar bir kadın duyarlıığı ile dile getirilmiştir. Sırpça orijinali kaybolan bu kronik 1976 yılında Voislav Maksimoviç ve Luka Şekara tarafından Rusçadan Sırpçaya çevrilmiş ve Sarayevo'da "Kronikler. Prokopije Çokorilo, Joanikije Pamuçina, Staka Skenderova" adıyla açıklamalarla donatılarak yayınlanmıştır (Maksimoviç, Şekara, 1976).

Eserin adından anlaşılacağı gibi, Bosnalı Sırp rahip İoanikije Pamuçina'nın Ali Paşa'nın hayatını anlattığı çalışması ve Sırp rahip Porokoij Çokorilo'nun Bosna kroniği ile ilgili çalışması da bu yayında yer almaktadır.

Pamuçina'nın çalışması ilk olarak 1856 yılında "Russkaya Beseda" adlı derginin 34- 36 sayfaları arasında "1841 Yılında Mostar'da Hristiyan Bir Kızın Yargılanması" adıyla yayınlanmıştır (Melçakova, 2020a, s. 231).

Daha sonra aynı eser "Hersek Veziri, Yöneticisi Ali Paşa Rizvanbevoviç'in Hayatı" başlığı ile Gilferding'in 1859 yayınında 473- 548, daha sonra yine Gilferding'in eserlerinin üçüncü cildinde (1873) sayfa 329- 378 arasında yayınlanmış ve eserin çevirmeninin Gilferding değil, D. Karyakin olduğu belirtilmiştir (Gilferding, 1873, s. 379). 
Sırp rahip Porokoij Çokorilo'nun çalışması da ilk olarak "Russkaya Beseda" (1858) dergisinin, 93- 121 sayfaları arasında daha sonra Gilferding'in 1873 yılında toplu eserlerinin üçüncü cildinde 499- 525 sayfaları arasında yer alır.

Melçakova, bu yayının Balkanların bu bölgesi ile ilgili Rusça ilk yayın olduğunu (Melçakova, 2020b, s. 213) ve bu eserin 1830- 1850 arası bu bölge tarihi için önemli bir kaynak olduğunu belirtir (Melçakova, 2020b, s. 215).

Genel olarak Rus araştırmacı Melçakova çalışmalarında Sırp rahibe Staka Skenderova'nın Sırpça yayının kaybolduğunu (Melçakova, 2015. 153), Gilferding'in Rusçaya çevirmiş olması sayesinde eserin tekrar Sırpçaya çevrildiğini belirtmesine karşın diğer iki din adamının eserlerinin Sırpça baskılarının kaybolması veya kaybolmaması hakkında bir bilgi vermemektedir. Biz, onların eserlerinin de Rusçadan çevrilmiş olmasından dolayı, bu eserlerin kaybolmuş olduğu şeklinde düşünebiliriz.

\section{Sırp Rahibe Staka Skenderova'ya Destek Çıkan Osmanlı Yönetimi}

Sırp rahibe Staka Skenderova (1830-1891), Bosna'daki kız çocuklarının okuması için bir okul açma girişiminde bulunmuş ve bu okula destek dönemin valisi Veliudin Paşa'dan gelmiş, Ortodoks Sırplar Osmanlı valisinin himayesindeki bu okula kız çocuklarını göndermek istememişlerdir (Melçakova, 2015, s.153).

Okulun faaliyet tarihi ile ilgili bilgi karışıklığı bulunmaktadır. Bir süre sonra okulun kapandığı, daha sonra okul için rahibe Staka'nın 1862 yılında Bosna Valisi Topal Şerif Osman Paşa'dan destek aldığı, açılan okula Paşa'nın kendi kızlarını da gönderdiği belirtilmektedir (Melçakova, s. 155). Bazı kaynaklara göre Haç yolcuğu sırasında Staka'nın İstanbul'a geldiği ve Topal Şerif Osman Paşa'nın aracılığı ile Sultan Abdülaziz ile görüştüğüu de bildirilmektedir (Melçakova, 2015, s. 155).

\section{Gilferding'in Farklı Coğrafyalardaki Slavlara Bakışı}

Panslavist düşüncelere sahip olan Gilferding'in farklı tarihlerde çıkan yazıları 2009 yılında "Gilferding. Rusya ve Panslavizm" adıyla düzenlenerek yayınlanmıştır. Bu çalışmada yer alan "Avusturya ve Türkiye'de Slav Halkları" (32-46) ${ }^{8}$ adlı bölümde Gilferding'in Slav halkları ile Rusların kardeşliği düşüncesi şu şekilde yansımıştır.

“Çarlık Rusya'sının sınırlarından batıya ve güney batıya doğru, konuşmalarını Rus'un anladığı, onların atalarıyla Rus'un atasının aynı kabileden olduğu halklar yer alır. Bu halkların çoğunluğu bizim Ortodoks inancımızdadır ve Tanrıya bizimle

\footnotetext{
${ }^{8}$ Bu yazı ilk olarak 1860 yılında "Narodnoe Çtenie" dergisinde, daha sonra Gilferding'in toplu eserlerinin ikinci cildinden 1868 yılında yayınlanmıştır.
} 
aynı dilde dua eder. Bu halklar, Rusların kardeşleridir ve Rusları kardeş gibi severler- onlara Slav denir" (Gilferding, 2009, s. 33).

Ona göre, Balkanlarda bir milyon Türk, sekiz milyon da Slav vardır... "Yabancılar bu sekiz milyonun bizlerle dostluğundan korkarlar... Fransızların, özellikle de Ingiliz ve Almanların amacı bizim Türk Slavları dışlamamızdır; onlar Türk Slavların Rusya'dan medet ummayı kesmelerini isterler" (Gilferding, 2009, s. 33-34).

Gilferding'in bu sayısal verilerinin temelinde hangi araştırmanın yer aldığı bilinmemektedir. Ona göre, olması gereken sayı sekiz milyondur ve Osmanlı politikaları sonucu bu sayı azalmaktadır. O, "Türkiye'deki Sırplar ve Bulgarlar dayanılmaz bir boyunduruk altında ızdırap çekmektedirler: onlardan pek çoğu bu ızdıraplardan kurtulmak için Müslüman inancını kabul ettiler, Türk olarak yeniden doğup kendi kardeşlerinin zalimleri oldular" (Gilferding, 2009, s. 37) diyerek asimilasyon kavramını vurgulamıştır.

Daha sonra Avusturya'da ve Türkiye'de yaşayan Slavların durumunu değerlendiren Gilferding, Türkiye'deki Slavların durumunun Avusturya'daki toplumdan daha kötü olduğunu iddia etmektedir:

“Fakat her durumda, Türkiye'deki Slavlar yıldan yıla daha ağır koşullarda yaşamaktadırlar. Gerçekte, Türkler şimdi eski gibi vahşi değiller; onlar Avrupa davranış biçimini benimsemeye başladılar, pek çoğu Fransızca öğrendi: fakat insanın ruhu aydınlanmamışsa eğitimli bir Avrupalının tarzı insanı iyi yapmaz, Türkün ruhu sadece aydınlanmamakla kalmamış, aynı zamanda bozulmuştur da. Eskiden onlar peygamberleri Muhammed'e inanırlardı; şimdi hiçbir şeye inanmıyorlar. Onlar eskiden vahşi, fakat saf ve iyi karakterliydiler, şimdi ise saygılı, fakat sinsi oldular. Onlar Avusturyalılarla iyi arkadaşlar, çünkü her ikisinin de ortak hesapları, Slavlara geçit vermemektir" (Gilferding, 2009, s. 44-45).

Gilferding'in çalışmalarını Panslavist teori belirgin bir şekilde etkilemiştir. Onun 1853 yılında yayınlanan Slavcanın Sankritçe ile akrabalığı tezini savunduğu çalışması, yine Bosna sonrasındaki çalışma döneminin ürünü olan üç ciltlik (1. Cilt 1894, 2. Cilt 1896, 3. Cilt 1900) Onega bölgesi destanları çalışması tamamen Rus kültürünün üstünlüğünü kanıtlama amacına hizmet etmektedir.

\section{Panslavizmden Etkilenip Balkan Topraklarına Gelen Rus Gönüllüler}

Yukarıda belirttiğimiz üç diplomat dışında aynı tarihlerde Balkanlardaki isyanlara yardımcı olmak veya herhangi bir alanda Balkan Slav toplumlarına destek vermek için Balkan topraklarına gelen Rus gönüllüler de vardır. Balkan topraklarına gelen Rus gönüllüler üzerine çalışan Sergey Anatolyeviç Koçukov, fotoğraf kayıtlarından hareketle oluşturduğu makalesinde Balkan topraklarına gönüllü 
gönderilmesi ile Moskova ve Peterburg'daki Slav Yardım Komitelerinin ilgilendiğini belirtir.

“Bütün gönüllüler aynı işlemlerden geçtiler. Gitmek için Slav Yardım Komitesine dilekçe vermeleri gerekiyordu. Benzer dilekçeler yazıldı, gönüllüler oldukça alacalı bir kadro oluşturuyorlardı, büfedeki tezgâhtardan memura. Hemşire olarak çalışmak isteyen kadınlardan da pek çok dilekçe geldi" (Koçukov, 2015a, s. 389).

Nikitin, yardım komitelerinin gönüllülerin gönderilme paralarını karşıladıklarını belirtmekte ve 1 Eylül 1875'ten 22 Ekim 1876'ya kadar 742.000 ruble toplandığını ve bunun 383. 500 rublesinin gönüllülere yolluk için harcandığını belirtmektedir (Nikitin, 1960, s. 311).

Onun verilerine göre, Ekim 1876 tarihinde Balkanlara Moskova Komitesi 1176, Peterburg 816, Varşova ise 43 gönüllü göndermiştir. 1877 tarihinde ise 2552 gönüllü (646 subay ve 1806 sivil) (Nikitin, 1960, s. 319) gönderilmiştir.

Elbette bu dönemde Balkan topraklarına Rus gönüllülerin gidişini desteklemeyen gruplar da bulunmaktaydı. 1870'li yıllarda yurt dışında yayın yapan "Nabat" adlı gazete, Balkanlardaki savaşa farklı bir şekilde bakıyordu:

"Slavların isyanını onaylamak ve desteklemek çifte kötülüktür: bu davranış, halkı kan dökmeye ve ileride gerçekleşmeyecek yalan bir vaat için çocuklarını yok etmeye yönelterek isyan bölgelerindeki zavallı halkı aldatmaktır. Halk, bu mücadeleye daha çok hazırlanması gerektiğini unutacak ve bir Rus gibi, doğrudan savaşa atılacaktır" (Koçukov, 2015b, s. 92).

Nijegorod vilayetinden zengin bir çiftlik sahibi Vasiliy Vasilyeviç Yaşçerov, Panslavist düşüncelerin etkisiyle 1876 yılında gönüllü olarak Sırbistan’a gelmiş ve duygusal içerikli gözlemlerinden oluşan "1876-1877 Yılında Sırbistan'da Bir Gönüllünün Notları"9 adlı yazısını yayınlanmıştır (Yaşçerov, 2006, s. 243-247).

Yaşçerov, Sırp halkını övdüğü yazısında şöyle der: "Sırp halkına özgü bir nitelik de aşırı dürüstlüktür: burada hırsızlık hemen hemen yoktur" (Yaşçerov, 2006, s. 246).

Hatıralarını yazıya döken bir başka gönüllü, 1876 Sırp- Türk savaşına katılan Rus gönüllü A. N. Hvostov ise "Sırplar iyi huylu ve ilişkilerde yumuşak olmalarıyla ayırt edilmektedirler: yumuşaklıkta onlar Lehlerden hiç de geri kalmazlar, fakat kibirli değillerdir. Onlar hareketlerinde ölçülü ve Maloruslar gibi açık sözlü, fakat

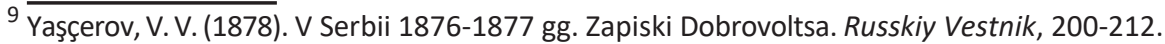


sinsi değillerdir. Bunun nedenini ben asırlardır süren köleliğin sonucu olan zayıflıkta gördüm" (Hvostov, 2006, s. 234-235).

Gönüllülerin bu tür çalışmalarını yorumlayan Romaşov, "Rusya ve Balkan Slavlarının yakınlığı düşüncesinin güçlenmesi hem Rusya- Balkan ilişkilerinin idealleşmesi hem de Rusya'nın Balkanlardaki çıkarlarını ortaya koyan politik planların açıklanması ile bağlantılıdır" (Romaşov, 2012, s. 50) şeklinde bir görüş ileri sürmüştür.

Burada bir aç örneğini verdiğimiz gönüllü mektupları, sadece Rus toplumu içinde Balkanlara ilginin artmasını sağlamıştır ve hiçbiri ayrıntılı bir inceleme veya yaklaşım içermemektedir.

\section{Balkanların Fotografik Arşivi. Balkanlarda illk Rus Fotoğrafçı}

Ülkesindeki Panslavistlerin etkisi altında kalan fotoğrafçı Petr Pavloviç Pyanitskiy, 1867 yılında Türk hâkimiyeti altında bulunan Bosna vilayetine gelir. Onun temel amacı gündelik yaşamdan çok bu bölgedeki Hristiyanlık yapılarını fotoğraflamaktır. Seksen fotoğraftan oluşan çalışması 1867 yılında Peterburg'da albüm olarak yayınlanır ${ }^{10}$. Bu çalışmayı değerlendiren araştırmacı Kseniya Valeryevna Melçakova, çalışmada az sayıda da olsa Müslüman yerli halka yer verildiğini ve bunlar arasında derviş, Osmanlı memuru, binbaşı, yüzbaşı, Türk kızı, Bosnalı Arap, Bosnalı Türk, Türk köylülerin yer aldığını (Melçakova, 2018, s. 65) belirtmektedir.

Pyanitskiy'in çalışması, Balkan topraklarında gerçekleştirilmiş ilk fotografik çalışmalardan biri olarak kayıtlara geçmiştir.

\section{Askeri Tarihçi Nikolay Romanoviç Ovsyanıy}

Askeri tarihçi, yazar, binbaşı Nikolay Romanoviç Ovsyanıy da (1847- 1913) pek çok Balkan halkı ve ülkesi üzerine kitaplar kaleme aldı. Slav kardeşliği taraftarı olan Ovsyanıy, Bulgaristan'ı çok yönlü ele aldığı çalışmasının önsözünde "Artık kabile akrabalığından ve inanç birliğinden bahsetmeden tek bir nedenle Rus kanıyla sulanmış Bulgaristan topraklarında Bulgar özgürlüğü gelişiyor, Bulgar halkının kaderi özellikle bizlere daha yakın olmalı. Bizim ilişkilerimizin üzerinde Bulgaristan'ı Rusya'dan koparmak isteyen karanlık Stambulov ${ }^{11}$ hareketinin bulutları vardı. Fakat halk hareketi dalgası hem Stambulov'u hem de onun kirli amacını yok etti" (Ovsyanıy, 1900, s. 5) diyerek Bulgaristan’ın pek çok açıdan Rusya'ya

\footnotetext{
${ }^{10}$ Fotografiçeskiy Sbornik Tserkovnıh Drevnostey i tipov Slavyan Evropeyskoy Turtsii. Gertsegovina i Bosnija 1867 goda, Peterburg, 1867.

${ }^{11}$ 1887-1894 tarihleri Bulgaristan'ın başbakanı olan Stefan Nikolov Stambulov (1854-1895), Bulgaristan'ın Rusya etkisinden çıkmasına yönelik politikası yüzünden Türkçü olarak tanımlanmıştır.
} 
bağlı olması gerektiğini vurgular.

Ovsyanıy'ı Balkan topraklarında bulunan diğer Rus araştırmacılardan ayırt eden bir özelliği, onun aynı zamanda Türkiye'yi iyi tanıması ve ülkemizde gerçekleştirdiği seyahatlerdeki gözlemlerini yazıya dökmüş olmasıdır.

Ovsyanıy, Balkan topraklarındaki Slav halklarını daha iyi anlamak için Anadolu insanını da ayrıntılı bir şekilde inceleme intiyacı duymuştur. O, 1877 yılında Peterburg'da yayınlanan "Çağdaş Türkiye" (Sovremennaya Turtsiya) adlı çalışmasını on iki bölüm olarak kurgulamış, bu bölümlerde köleler, harem, eğitim gibi pek çok konuyu ele almıştır. Diğer pek çok Panslavist gibi onun da bakış açısı olumsuzluk içermektedir.

Örneğin "Türklerin Yaşam Biçimi" (15-28) başlığı altında Ovsyanıy şu görüşlere yer verir:

“Dış görünüş, karakter ve yaşam biçimi olarak Türkler, Avrupa'nın diğer halklarından, özellikle de güneydekilerden kesin bir şekilde ayrılmaktadırlar. İslamiyet ile bütünleşmiş doğu alışkanlıkları onlara kendilerine özgü bir renk vermiştir: onların geleneklerinde şimdiye dek sadece göçebe halklara özgü olan çizgilerle de karşılaşılmaktadır" (Ovsyanıy, 1877, s. 15).

Daha sonra Ovsyanıy Türk tipi ve genel kişilik özellikleri hakkında biraz daha olumlu bir yaklaşım sergilemektedir.

"Türk uzun boylu ve geniş omuzludur, sakal ve bıyık bırakır; geniş burnu aşağı doğrudur, alnı yüksek, gözleri yumuşak ve kısıktır. Hareketleri sakin, becerikli, güvenlidir. Jestlerinde, sözlerinde, duygularını ifadesinde her zaman farklıdır; hiçbir zaman küfür etmez, ender olarak öfkeye kapılır ve dertleri onda sakin, gürültüsüz bir şekilde ifade edilir. Fakat bu eylemsizlik, öz güven maskesinin altında tembellik ve ilgisizlik saklıdı" (Ovsyanıy, 1877, s. 15-16).

Ovsyanıy, çalışmasının "Din ve Törenler" (70-96) kısmında şöyle yazar:

"Türklerin bir bütün olarak kabul ettikleri İslamiyet onların dini ve politik, vatandaş ve aile yaşamlarının temel dayanağını oluşturmaktadır. İslamiyet sayesinde Osmanlılar Avrupa'da yerleşti ve geniş, fakat geçmişte bu kadar da güçlü olmayan bir devlet kurdular. Fakat bu din yine de onların durgunluğunun ve hareketsizliğinin nedeni oldu" (Ovsyanıy, 1877, s. 70).

Ovsyanıy'ın farklı tarihlerde kaleme aldığı makaleler onun öldüğü yıl (1913) "Yakın Doğu ve Slavlık" (Blijnıy Vostok i Slavyanstvo) adıyla yayınlanmıştır. Bu çalışmada Ovsyanıy’ın “Müslüman Sırpların tarihi” (s. 71-102), "1876 Sırp- Türk Sa- 
vaşı" (s. 141-221), "Makedonya'ya Kimler Yerleşmeli?" (s. 230-257) gibi yazıları yer alır (Ovsyanıy, 1913).

\section{Balkan Topraklarında Liberal Bir Seyyah}

Rus seyyah, etnograf ve yazar olarak da tanınan Yevgeniy Lvoviç Markov (1835-1903), pek çok Türk ülkesinde ${ }^{12}$ seyahat etmiş ve farklı tarihlerde seyahat gözlemlerini yayınlamıştır. Yazıları ve hayata bakışı temelde uzlaşmacı bir liberal olarak tanımlanan Markov, aşırı düşüncelerden uzak soylu sınıfın klasik bir temsilcisidir (Klemenskiy, 1932, s. 815-816).

Markov'un 1903 yılında çıkan "Sırbistan ve Karadağ'da Seyahat" kitabı onun Balkan gözlemlerini içerir. Kitap üç bölümden oluşmaktadır: "Kardeş Topraklarda" (1-169), "Sırbistan'ın Baş Şehri" (170-255), "Slav Spartası" (256-509). Bu seyahat notlarında Markov, kendi düşünce ve gözlemlerini sohbet ettiği Molo adlı bir Yahudinin sözleriyle verir. Seyyahın ilk şehri Selanik'tir. Yahudi Molo, ona şehir ile ilgili düşüncelerini şöyle açıklar:

“Lütfen, siz Selanik'in bir Türk şehri olduğunu düşünmeyiniz, evet burada Türk barbarlığı var!... Bizdeki vali bir Türk paşasıdır, hepsi bu... Elbette Selanik'te Yunanlılar da yaşar, Slavlar da var, fakat Slavlar basit bir halktır, köylüdürler... Bizde Yunancayı ve Slavcayı İspanyolcadan daha az duyarsını" (Markov, 1903, s.2)

Onun 1886 yılında "Vestnik Evropı" dergisinde yayınlanan "Doğu Avrupa. Yol Yazıları" adlı uzun makalesi İstanbul'un tasvirine ve gündelik yaşama belirgin bir yer ayırmıştır (Markov, 1886, s. 116-176).

İstanbul'a deniz yolculuğu ile ulaşan Markov, Üsküdar, Çırağan sarayı, hisarları, boğazın güzelliğini notlarında belirtir. Daha karaya ayak basmadan gördüğü minareler onda hem hayranlık hem de İstanbul'u fethedenin dinine karşı karamsar düşünceler oluşturur:

“Fakat minareler sadece dua eden halka ışık vermekle kalmaz: Allah'ın göğüne sivri uçlarını batıran ve Hristiyanlığın başkentini diz çöktürten İslamiyet ile dost olmuş taş mızrakların sık ormanıdır" (Markov, 1886, s. 134).

Seyahat notlarında Türk damak zevkinden etkilenen seyyah, özellikle bunu şu şekilde vurgular.

"Demir bir şişe dizilmiş kuzu şişin tadı ve yağı hakkında söylenebilecek hiçbir şey yok, Paris veya Peterburg'un en lüks restoranında bile yiyemezsin" (Markov,

\footnotetext{
${ }^{12}$ Markov, Türkmenistan, Buhara, Semerkant, Kırım ve Kafkasya'ya yolculuk yapmış ve bu yolculuk notlarını farklı tarihlerde yayınlamıştır.
} 
1886 , s. 155).

Markov'un liberal yaklaşımı, onun notlarında Türk yaşam biçimi ve toplumsal yardımlaşması ile ilgili olarak olumlu bir bakış açısı geliştirmesini sağlamıştır. Özellikle toplumsal dayanışmanın yansıması olan aş evleri ve camilerin hizmetini şu sözlerle dile getirir.

"Beyazıt cami eskiden beri haftada iki gün binlerce fakiri besliyor, Ramazan ayının kutsal günlerinde ise her Allah'ın günü. Diğer büyük bir cami olan Süleymaniye her gün altı yüz yoksulu doyuruyor" (Markov, 1886, s. 168).

\section{Bulgaristan İzlenimlerini Yazıya Döken Doktor Sergey Petroviç Botkin}

Rus Doktor Sergey Petroviç Botkin (1832-1889), ülkesinde daha çok salgın hastalıklara karşı bir sistem kurulması üzerine çalışmıştır.

Yönetim kademelerinde yer almayan Botkin, Kırım Savaşı'na ve 1877-1878 yıllarındaki Rus- Türk Savaşı'na gözlemci olarak katılmıştır. Kırım Savaşı'ndaki gözlemlerinden hareketle doktorların teorik bilgilerin yanı sıra pratik uygulamalarının da geliştirilmesi gerektiği tezini ileri sürmüştür... Rus- Türk Savaşı́nın sürdüğü zaman diliminde yedi ay boyunca İmparatorluk temsilcisi olarak Balkan topraklarında bulunmuştur (Belskih, 2012, s. 11).

Botkin'in günlük tarzında kaleme aldığı yazıları 1893 yılında Peterburg'da yayınlanır. Diğer çalışmalardan farklı olarak bu çalışmada Bulgaristan'daki hastanelerin durumu, nasıl geliştirileceği ile ilgili düşünce ve gözlemler yeralır.

Botkin, bir gözlemcidir, onun diğer Balkan topraklarında bulunan Panslavist diplomat, gönüllü ve seyyahlar gibi Türklere karşı olumsuz yaklaşımları bulunmamakla birlikte, çok da olumlu olduğunu söylemek mümkün değildir.

Botkin'in yazılarında çok az yerde Türklerle ilgili gözlemleri yer alır:

“Öğle yemeğinden sonra konvoy halinde esir Türkleri getirdiler; onları büyük bir ilgiyle gözlemledim; burada nizamlar, Başıbozuklar vardı. En ilginç tipler elbette Başıbozuklardı: zayıf, kaslı, figürleri vahşi ifadeli, üstleri yırtıktı; bazılarının başında türbanlar vardı; nizamlar çoğunlukla sakin bir görünüme sahiptiler, çok zayıf değillerdi, bazıları hatta biraz semizdi; burada yüzleri küt Kırım Tatarları da vardı" (Botkin, 1893, s. 39-40).

Pavlova adlı köyde kalırken Botkin, Bulgar ev sahibinin giyim ve davranış biçimi olarak Türk çizgilerine sahip olduğunu belirterek şu gözlemini dile getirir:

“Bulgar kültürü, az da olsa yok olmamış, görünüşe göre Türkler Bulgarları o 
kadar etkilemişler ki, Türkçe Bulgarcadan daha fazla yaygınlık kazanmış burada" (Botkin, 1893, s. 72).

\section{Sonuç}

Çarlık Rusya'sında XIX. yüzyılın öncesi dönemde Balkan topraklarında yaşayan Slav halklarına yönelik kapsamlı ve bilimsel nitelikte bir inceleme yapılmamıştır. Bu dönemden önceki birkaç seyahatname ya dini görevler nedeniyle bu topraklarda bulunan din adamları ya da tüccarlar tarafından gerçekleştirilmiştir.

XIX. yüzyılın ilk yıllarından itibaren Rusya'da gelişen Panslavist yönelimler, Rusya'nın kendisi dışındaki Slav kökenli halklara yönelmesini sağlamıştır. Bu nedenle de Rusya toprakları dışında Slav halklarının yoğun olarak bulunduğu Balkan toprakları bir ilgi merkezi oluşturmuştur. Bu alandaki ilk çalışmalar konumları gereği daha rahat seyahat edebilen, kaynaklara ulaşmada sorun yaşamayan elçilik çalışanlarına aittir. Genel olarak "diplomat” unvanıyla tanımlanan bu araştırmacıların çoğunluğu, bu topraklara gelmeden önce ülkelerinde Panslavist fikirlerle beslenmiştir. Elbet bu durum, onların çalışmalarının belirli ön yargılar taşımasına da yol açmıştır. Onlar hiçbir şekilde Balkan topraklarındaki Müslüman ve Türk toplumlarını incelemek istememiş olsalar da çalışmalarında ister istemez bu toplumlara da değinmek zorunda kalmışlardır.

Daha sonraki yıllarda Balkan topraklarına gelen Rus gönüllüler, bu topraklarda edindikleri duygusal nitelikteki izlenimlerini çeşitli yayın organlarında yayınlatmışlardır. Bütün bu çalışmalar, Rusya'daki Balkan çalışmalarının temelini oluşturmuş, ileriki yıllarda bölge için yapılacak çalışmalara kaynak yaratımıştır.

Burada genel olarak değinmeye çalıştığımız ve genel olarak ön yargılı bu çaIışmalarda yazarlar ne kadar kaçınsalar da Türk, Müslüman gibi kavramlara yer vermiş, bazen Türk ve Müslüman toplumlarının değerlerinden hayranlıkla bahsetmişledir. Kaynaklar, Sırp rahibe Staka Skenderova'nın kadınların eğitimi için açmaya çalıştığı okula desteğin dindaşlarından değil, "barbar", "cahil”, "kan dökücü" Türk'ten geldiğini ortaya koymaktadır. Bu bilgi, Balkanlardaki Türk hâkimiyetinin insancıl yaklaşımını bir Sırp rahibenin dile getirmesi açısından önemlidir.

Bu makalede kısaca tanıttığımız çalışmaların ülkemizde gerçekleştirilecek Balkan alanındaki çalışmalarda kullanılmasının büyük bir yarar sağlayacağı aşikârdır. 


\section{Kaynakça}

Aslanova, S. (2008). 20. Yüzyılın Başında Rusya'nın Osmanlı Politikası (1903-1917). Dokuz Eylül Üniversitesi, İzmir (Yayınlanmamış Yüksek Lisans Tezi).

Belskih, A. N., Antonov, V. B., Bogdanov, A. N. (2012). Sergey Petroviç Botkin i Ego Vklad v Razvitie Imperatorskoy Voenno- Meditsiınskoy Akademii. Vestnik Rossiysko Voenno-Meditsinskoy Akademii, (3), 7-14.

Bilge, M. L. (2008). Ali Paşa Rıdvanbegoviç. TDV İslam Ansiklopedisi, c. $35,50-51$.

Botkin, S. P. (1893). Pisma S. P. Botkina iz Bolgarii v 1877 g. Peterburg.

Berdyayev, N. (1926). Konstantin Leontyev. Oçerk iz istorii russkoy religioznoy misli. Paris.

Bulahov, M. G. (1978). Osnovnıe Etapı razvitiya Slavyanskogo Yazıkoznaniya v Rossii (do 1917 g). Metodologiçeskie Problemı Istorii Slavistiki, Moskova, 56-87.

Çağ, G. (2008). Panslavizmin Fikri Temelleri ve Slav Birliği Çabaları. Sakarya Üniversitesi, Fen Edebiyat Fakültesi Dergisi, Orhan Hülagü Özel SayısI, 10(1), 205-220.

Çetin Mehmet, Kök Recep, (2018). Kırım Savaşı Örneğinde Osmanlı Ordusu'nda Gayrimüslimlerin Istihdamı. Bilig, (85), 1-24.

Danilevskiy, N. Y. (1991). Rossiya i Evropa, Moskova.

Demiroğlu, H. (2009). Rus Kaynaklarına Göre Rusya'nın Balkan Siyaseti: Ortodoks Birliği ve Panislavizm (1856-1878). (Yayınlanmamıs Doktora Tezi), İstanbul.

Duranlı, M. (2012). Rus Yazar Konstantin Nikolayeviç Leontyev'in Eserlerinde Balkanlar ve Yazarın 'Pembe' Adlı Hikâyesi. Türk Dünyası Incelemeleri Dergisi, XII(2), 477-490.

Gilferding, A. (1859). Bosniya, Gertsovina i staraya Serbiya, Sbornik Sostavlennıy A. Gilferdingom. Peterburg.

Gilferding, A. (1873). Sobranie Soçineniya Gilferdinga.Bosniya, Gertsovina i Staraya Serbiya. c. 3, Peterburg. 
Gilferding, A. (2009). Slavyanskie Narodı v Avstrii i Turtsii. Rossiya i Slavyanstvo, Moskova: Institut Russkoy Tsivilizatsii, 32-47.

Hvostov, A. N. (2006). Russkie i Serbı v Voynu 1876 g. za Nezavisimost Hristian, Pisma. Russkie O Serbii i Serbah, Peterburg, 232-242.

Klemenskiy, M. (1932). Markov. Sovetskaya Entsiklopediya, c. 6, 815816.

Koçukov, S. A. (2015a). Russkie Dobrovoltsı na Balkanah v 1876 godu (Po Materialam Vizualnıh İstoçnikov). Voyna i Orujie. Novıe İssledovaniya i Materialı, Peterburg, 2, 386-399.

Koçukov, S. A. (2015b). Russkie Dobrovoltsı v Serbo- Turetskoy Voyne 1876 Goda V Zerkale Vospominaniy V. V. Yaşçerova. İstoriya i İstoriçeskaya Pamyat, Saratov, 89-103.

Konoplyantsev, A. M., Aleksandrov, A. A., Rozanov, V. V. (1911). Pamyati Konstantina Nikolayeviça Leontyeva. $1891 \mathrm{~g}$. Peterburg,

Kurat, A. Nimet (1953). Panslavizm. DTCF Dergisi, II(4), 241-278.

Lebedev. S. (2009). Predislovie. Rossiya i Slavyanstvo, Moskova, 5-31.

Leontyev, K. N. (1875). Vizantizm i Slavyanstvo, Çteniya İmperatorskom Obş̧estve Istorii i Drevnostey Rossiyskoy Pri Moskovskom Universitete, Moskova, No 3.

Leontyev, K. N. (1912). Sobranie Soçineniy. K. Leontyeva. C. 2, Moskova.

Leontyev, K. N. (2001). Pembe. Povest Epir-Albanskoy Jizni. Polnoe Sobranie Soçineniy i Polnoe Sobranie Soçineniy i Polnoe Sobranie Soçineniy i Polnoe Sobranie Soçineniy i Pisma, S. Peterburg, c. 3, 88-146.

Maksimoviç, V- Şekara, L. (1976). Letopisi. Prokopije Çokorilo, Joanikije Pamuçina, Staka Skenderova, Sarayevo.

Markov, E. L. (1886). Evropeyskiy Vostok. Putevie Zapiski. 1. Na Rubeje. Vestnik Evropı, 3, 116-176.

Markov, E. L. (1903). Puteşestvie Po Serbii i Çernogorii. Peterburg. Melçakova, K. V. (2015). Problema Jenskogo Obrazovaniya v Bosnii. 
Staka Skenderova: Eyo Jizn, Eyo Şkola. İvestiya Samarskogo Nauçnogo Tsentra Rossiyskoy Akademii Nauk, 17(3), 152-157.

Melçakova, K. V. (2017). Slavyane- Musulmane Bosnii i Gertsegovinı V Trudah A. F. Gilferdinga. Slavyanskiy Mir v Tretyem Tısyaçeletii. Etniçeskie, Konfessionalnıe, Sotsiokulturnı Komponentı Identiçnosti Narodov Tsentralnoy, Vostoçnoy i Yugı- Vostoçnoy Evropı, Moskova, 175-183.

Melçakova, K. V. (2018). Bosniysiy vilayet v obyektive fotografa P. P. Pyanitskogo. Slavyanskiy mir v tretyem tısyaçeletii, (13), 60-71.

Melçakova, (2020a). Gertsegovinskiy Narodnıy Mitropolit İoannikiy Pamuçina. Materialı Dlya Virtualnogo Muzeya Slavyanskih Kultur, (1), Moskova, 229-234.

Melçakova, (2020b). Letopisets Gertsegovinı Prokopiy Çokoroli i Rossiya. Materialı Dlya Virtualnogo Muzeya slavyanskih Kultur, (1), Moskova, 213-218.

Momçilo, i. (1904). İvan Stepanoviç Jastrebov. Spomenik, 41, 1-11. Nikitin,S. A. (1960). Slavyanskie Komitetı v Rossii v 1858-1876 godah. Moskova.

Ovsyanıy, N. R. (1900). Bolgariya i Bolgari. Peterburg.

Ovsyanıy, N. R. (1913). Blijnıy Vostok i Slavyanstvo. Sbobrnik Statey, S. Peterburg.

Pıpin, A. N. (1889). Russkoe Slavyanovedenie v XIX-m Stoletii. Vestnik Evropı, (7), 238-274.

Palienko, M. G, Srinyak, i. V. (2018). Dmitriy Bantış-Kamenskiy (17881850): Portret İstorika v Kontekste Epohi. Ruski, 52, 221-237.

Popovkin, A. A. (2011). Moskovskiy Slavyanskiy Komitet i Obşçestvennaya Blagotvoritelnost v Rossii (1858- 1874 gg). Vestnik Tomskogo Gosudarstvennogo Universiteta, Gumanitarnıe Nauki. Istoriya i Politologiya, (8), 268-272.

Romaşov,Y. V. (2012). Balkanı V Vospriyatii Russkih Vo Vtoroy Polovine XIX Veka: Slavyanskoe Edinstv i Otçujdenie. İzvestiya Saratovskogo Universiteta, c. 12. Seriya. İstoriya. Mejdunarodnı Otnoşeniya, 3(3), 47-50. 
Terziç, S. (2014). Russkiy Konsul i. S. Yastrebov o Staroy Serbii. i̇z İstorii Serbii i Russko- Serbskih Svyazey: 1812- 1912- 2012, Moskova, 125-134.

Yastrebov, i. S. (1866). Obıçai i Pesni Turetskih Serbov v Prizrene, İpeke, Morave i Dibre. Peterburg, (Kitabın genişletilmiş baskısı 1889 tekrar Peterburg' da yayınlanmıştır.)

Yastrebov, i. S. (1904). Stara Serbiya i Albania. Putevye Zapiski. Spomenik, 41, 1-267.

Yaşçerov, V. (2006). V Serbii 1876- 1877 gg. Zapiski Dobrovoltsa. Russkie O Serbii i Serbah, Peterburg, 243-247. 